\title{
Seasonal Variation of Landfill Methane and Carbon Dioxide Emissions in a Tropical Climate
}

\author{
Mohammed F. M. Abushammala, Noor Ezlin A. Basri, and Mohammad K. Younes
}

\begin{abstract}
Landfill gas (LFG) emissions were measured in a landfill in tropical conditions in Malaysia to investigate seasonal variations in methane $\left(\mathrm{CH}_{4}\right)$ and carbon dioxide $\left(\mathrm{CO}_{2}\right)$ emissions. The study results showed that $\mathrm{CH}_{4}$ and $\mathrm{CO}_{2}$ emissions were ranged from 0 to $1,602 \mathrm{~g} \mathrm{~m}^{-2} \mathrm{~d}^{-1}$ and 5 to $2,753 \mathrm{~g} \mathrm{~m}^{-2} \mathrm{~d}^{-1}$ during wet and dry seasons, respectively, and higher $\mathrm{CH}_{4}$ and $\mathrm{CO}_{2}$ emissions were found during the wet season than in the dry season. It is concluded that special consideration must be given to landfill cover soil in order to enhance $\mathrm{CH}_{4}$ oxidation and, thereby, reduce $\mathrm{CH}_{4}$ emissions.
\end{abstract}

Index Terms-LFG emission, landfill, methane emission, seasonal variation.

\section{INTRODUCTION}

Waste sectors in Malaysia contribute for greenhouse gas (GHG) emission with total Methane $\left(\mathrm{CH}_{4}\right)$ emission approximately 1.3 million metric tons (mmt) in 2004 which approximately $27 \mathrm{mmt}$ of carbon dioxide $\left(\mathrm{CO}_{2}\right)$ equivalent [1], where the most prominent $\mathrm{CH}_{4}$ emission source came from landfills $(53 \%)$, followed by palm oil mill effluent (38\%), swine manure $(6 \%)$ and industrial effluent $(3 \%)$.

No precise method for measuring landfill gas (LFG) emissions exists. A flux chamber method is a simple method used to measure LFG emissions and is characterized by relatively low cost, ease of use, and ability to investigate research objectives obtained by discrete observations in space and time [2]. Two types of flux chambers have been described in the literature to measure LFG emissions: static and dynamic flux chambers. The static flux chamber method is the most simple and frequently used [3]-[7].

Field measurements using flux chamber method indicated that $\mathrm{CH}_{4}$ emissions ranging from $0.4 \mathrm{mg} \mathrm{m}^{-2} \mathrm{~d}^{-1}$ to more than $4000 \mathrm{~g} \mathrm{~m}^{-2} \mathrm{~d}^{-1}$ [8]. Some comprehensive field measurements have revealed seasonal variations in LFG emissions at multiple landfills in subarctic and humid regions, whereas there is very few studies have been conducted to investigate seasonal variations of $\mathrm{CH}_{4}$ and $\mathrm{CO}_{2}$ emissions from landfills in tropical regions. Maurice and Lagerkvist [5] investigated seasonal variations of $\mathrm{CH}_{4}$ and $\mathrm{CO}_{2}$ emissions at three

Manuscript received May 2, 2015; revised September 15, 2015. This work was supported in part by the Universiti Kebangsaan Malaysia (UKM) under Grants UKM-GUP-ASPL-08-06-208 and FRGS/1/2013/TK03/UKM/02/5.

Mohammed F. M. Abushammala is with the Department of Civil Engineering, Middle East College, knowledge Oasis Muscat, P.B. No 79, Al Rusayl 124, Sultanate of Oman (e-mail: eng_abushammala@yahoo.com).

Noor Ezlin A. Basri and Mohammad K. Younes are with the Department of Civil and Structural Engineering, Faculty of Engineering and Built Environment, The National University of Malaysia, 43600 Bangi, Selangor, Malaysia (e-mail: ezlin@eng.ukm.my, mohyoumoh@hotmail.com). landfills in northern Sweden and Finland (subarctic climate) and found higher emissions during the winter season than the summer season. Einola et al. [9] reported higher $\mathrm{CH}_{4}$ emissions and lower $\mathrm{CH}_{4}$ oxidation during the coldest month in boreal climate (subarctic) and lower $\mathrm{CH}_{4}$ emissions with higher $\mathrm{CH}_{4}$ oxidation during less colder months. Fourie and Morris [10] investigated $\mathrm{CH}_{4}$ emissions in semi-arid climates using the static flux chamber method and reported higher $\mathrm{CH}_{4}$ emissions in the winter relative to the summer season. Zhang et al. [7] found that $\mathrm{CH}_{4}$ emissions from a landfill located at eastern China (humid subtropical climate) were higher in the winter than in the summer season. Wang-Yao et al. [11] measured $\mathrm{CH}_{4}$ emissions from seven landfills in Thailand (tropical climate) using the static flux chamber method and found higher $\mathrm{CH}_{4}$ emissions during the wet season than the dry season.

The objective of this research was to study the seasonal variations in $\mathrm{CH}_{4}$ and $\mathrm{CO}_{2}$ emissions from a landfill in a tropical climate in Malaysia.

\section{MATERIALS AND METHODS}

\section{A. Site Description}

The Jeram sanitary landfill was selected for conducting this study (Fig. 1).

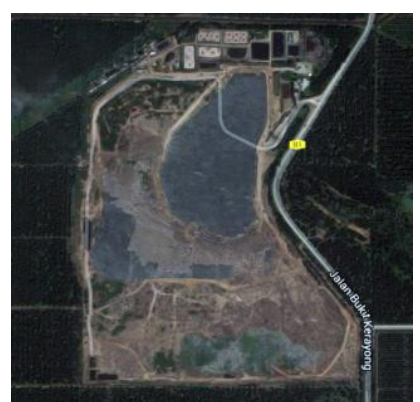

Fig. 1. Satellite view Jeram sanitary landfill.

It is currently operated by Worldwide Landfills Sdn. Bhd and located in Mukim Jeram, Selangor, $20 \mathrm{~km}$ northwest of Kuala Lumpur. It lies exactly between $3^{\circ} 11^{\prime} 20^{\prime \prime} \mathrm{N}$ and $101^{\circ} 21^{\prime} 50^{\prime \prime} \mathrm{E}$. The total landfill area is $52 \mathrm{ha}$, including six phases for waste disposal, and was designed to receive approximately 2,050 tons of municipal solid waste (MSW) per day for its 10-year operational lifespan that began in 2007.

The measurements were conducted at the advance cell. The waste at the advance cell had been covered for one year prior to when the field measurements were taken; the cell began receiving waste in April 2007 and was closed in April 2008 The cell was covered by poorly vegetated soil with an average thickness of $40 \mathrm{~cm}$. The average depth of the waste in the cell 
is approximately $10 \mathrm{~m}$. The cell was lined. At the time of the study, there was no gas collection system, and the waste gases escaped directly to the atmosphere.

\section{B. Measurement Strategy and Techniques}

To measure the LFG emissions from the cell surface in terms of spatial variability using geostatistics analysis, a $3,600 \mathrm{~m}^{2}$ square portion of the cell surface was overlaid with a $10 \times 10 \mathrm{~m}$ grid to identify critical measuring points. The grid square centers were marked with wooden sticks to specify sampling point locations [12]. Furthermore, additional sampling locations were marked at shorter distances to provide an adequate number of samples to better develop a semi-variogram model and for defining the flux spatial variability at short distances [13]. A total of 81 measuring points were identified. These 81 points were believed to be sufficient for modeling the spatial distribution of $\mathrm{CH}_{4}$ and $\mathrm{CO}_{2}[14]$.

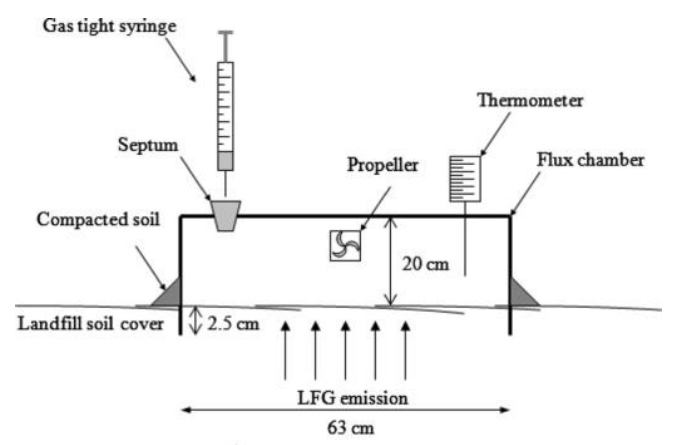

Fig. 2. Static flux chamber.

A square flux chamber was constructed to measure the $\mathrm{CH}_{4}$ and $\mathrm{CO}_{2}$ emissions from the landfill surface (Fig. 2). The flux chamber dimensions were selected based on a volume to area (V/A) ratio, where a typical flux chamber has a V/A ratio greater than $150 \mathrm{~L} \mathrm{~m}^{-2}$, as reported by Livingston and Hutchinson (1995). However, Fourie and Morris [10] reported that V/A ratios varied in the literature, ranging from $60 \mathrm{~L} \mathrm{~m}^{-2}$ to $300 \mathrm{~L} \mathrm{~m}^{-2}$. Thus, the V/A ratio for the static flux chamber used in the current study was $200 \mathrm{~L} \mathrm{~m}^{-2}$, in accordance with the research by Stern et al. [15]. Livingston and Hutchinson (1995) reported that typical flux chamber areas range from $175 \mathrm{~cm}^{2}$ to $1 \mathrm{~m}^{2}$, while an area of 500-900 $\mathrm{cm}^{2}$ is the most common. The enclosed area of the flux chamber used in the present study was $0.4 \mathrm{~m}^{2}$ [15]. The flux chamber area was chosen to meet the objectives of this research; the area is small enough that the environmental controls can be assumed to be uniformly distributed over the enclosed surface area and large enough to avoid restricting the spatial variability of the emission rate.

Some materials, such as aluminum, stainless steel, and various types of plastics, can be used for flux chamber construction [2]. Such materials can be employed for trapping non-reactive gases, such as $\mathrm{CH}_{4}$. Acrylic material was selected for the flux chamber construction in accordance with Eun et al. [16], whereas it is non-permeable, non-reactive and not a source or sink for either gas. Furthermore, acrylic material is lighter in weight than other materials such as aluminum and stainless steel which facilitates the chamber portability. The gas sampling port connector of the flux chamber was made from stainless steel. Puresep-T septa
(Cole-parmer), made of polytetrafluoroethylene (PTFE) and polyimide films on silicone rubber bases, was fixed at the sampling port to facilitate syringe injections during sample collection (Fig. 2). A digital temperature module, ETP104A, was used to measure the gas temperature inside the chamber, with working temperature of $0-50{ }^{\circ} \mathrm{C}$, and accuracy of \pm 1.5 ${ }^{\circ} \mathrm{C}$. To attain sufficient mixing of the gases inside the chamber, a small propeller was fixed inside the chamber and used during sample collection [17]. An umbrella was used during the emission measurements to avoid elevation of the internal chamber temperature as a result of solar radiation, which could cause changes in the measurements of gas concentrations per volume basis at the sampling locations [16].

The flux chamber was carefully positioned to maintain the natural processes that govern gas emission. The chamber was inserted $2.5 \mathrm{~cm}$ into the landfill cover soil to prevent environmental effects [18]. The insertion process was performed in regions of predominantly smooth cover soil. A sharp knife was used to cut a part of the surface cover soil where rigid soil was located to facilitate flux chamber base insertion. Once the chamber was in place, the soil around the chamber walls was gently tamped with a density approximately equal to the surrounding soil [2] to prevent the escape of liberated gases. Four sequential gas samples were extracted from the chamber headspace into a $50 \mathrm{~mL}$ gas-tight syringe at predetermined intervals $(5 \mathrm{~min}$ ).

At each sampling point, four sequential gas samples were extracted from the chamber headspace into a $50 \mathrm{~mL}$ gas-tight syringe at predetermined intervals ( $5 \mathrm{~min}$ ). Based on 20 years of rainfall data (1990-2009) collected by the Department of Irrigation and Drainage (Jabatan Pengairan dan Saliran; JPS) in Ampang, Malaysia, September, October, November, and December were selected as the wet months at the Jeram landfill location, whereas January, February, March, and April were selected as the dry months. Thus, $\mathrm{CH}_{4}$ and $\mathrm{CO}_{2}$ emission measurements were performed once each month during September, October, November, and December 2010 to estimate the averages of $\mathrm{CH}_{4}$ and $\mathrm{CO}_{2}$ emissions during the wet season and once again during each month of January, February, March, and April for estimating the averages of $\mathrm{CH}_{4}$ and $\mathrm{CO}_{2}$ emissions during the dry season. Emission measurements were all obtained between 8:00 am and 11:00 am to minimize the effect of time of day. The atmospheric pressure and air temperature were monitored while the emissions were being measured.

Ambient weather conditions, such as atmospheric pressure and air temperature, were measured during sample collection using the Skymaster, SM-28, Speedtech instruments. The Skymaster weather meter has a range of -15 to $+50{ }^{\circ} \mathrm{C}$ for air temperature and 400-1100 mbar for barometric pressure. The accuracy of the measurements of air temperature and atmospheric pressure was $\pm 1{ }^{\circ} \mathrm{C}$ and \pm 2 mbar, respectively.

\section{Gas Concentration Analysis and Emission Calculation}

A Varian mobile Micro-GC (CP-4900) equipped with a PPQ (PolarPlot Q, $10 \mathrm{~m}$ ) column module was used to analyze the $\mathrm{CH}_{4}$ and $\mathrm{CO}_{2}$ concentrations. To ensure that the gas samples were dry before they were introduced to the Micro-GC, an external sample filter unit was fitted between 
the Micro-GC injector and the sampling device. Helium (99.999\%) was used as a carrier gas for the thermal conductivity detector (TCD) at a pressure of 80 psi. Further details of the Micro-GC are shown in Table I. Before entering the Micro-GC, the carrier gas was passed through an external gas clean moisture and oxygen filter to remove the suspended moisture and oxygen associated with the carrier gas. The removal of moisture and oxygen from the carrier gas could increase the column's efficiency, which can help to maintain the desired separation distances between the chromatogram peaks.

TABLE I: MICRO-GC PARAMETERS FOR GAS DETERMINATION

\begin{tabular}{|c|c|}
\hline Gas chromatography & Varian Micro-GC CP49000 \\
\hline Column & PPQ, $10 \mathrm{~m}$ \\
\hline Detector & TCD \\
\hline Oven temperature $\left({ }^{\circ} \mathrm{C}\right)$ & 40 \\
\hline Column head pressure $(\mathrm{kPa})$ & 150 \\
\hline Carrier and reference gas & Helium \\
\hline Detection of & $\mathrm{CH}_{4}$ and $\mathrm{CO}_{2}$ \\
\hline
\end{tabular}

The gas components from each sample were detected in a typical $1.5 \mathrm{~min}$ and automatically integrated using the Galaxie software. Due to the high utilization frequency of the Micro-GC, the Micro-GC was conditioned before each field day. The conditioning time was extended overnight to remove any water present inside the column as a result of the gas samples or the carrier gas. The conditioning was conducted by increasing the oven temperature of the PPQ column to $150{ }^{\circ} \mathrm{C}$ (maximum column oven temperature). Each gas sample was analyzed a minimum of two times, and the average was calculated to estimate the $\mathrm{CH}_{4}$ and $\mathrm{CO}_{2}$ emissions [18]. The $\mathrm{CH}_{4}$ and $\mathrm{CO}_{2}$ emissions, $\mathrm{F}\left(\mathrm{g} \mathrm{m}^{-2} \mathrm{~d}^{-1}\right)$, was calculated according to Abichou et al. [19]:

$$
F=P V M U\left(\frac{d c / d t}{A T R}\right)
$$

where $P$ is pressure ( $1 \mathrm{~atm}), V$ is the chamber volume $(80 \mathrm{~L})$, $M$ is the molar mass (16 and $44 \mathrm{~g} / \mathrm{mol}$ for $\mathrm{CH}_{4}$ and $\mathrm{CO}_{2}$, respectively), $U$ is the units conversion factor $(0.00144$ $\mathrm{Lmin} /(\mu \mathrm{L} \mathrm{d})), A$ is the area covered by the chamber $\left(0.4 \mathrm{~m}^{2}\right)$, $T$ is the chamber temperature $(\mathrm{K}), R$ is the gas constant $(0.08205 \mathrm{~L} \mathrm{~atm} /(\mathrm{K} \mathrm{mol}))$, and $d c / d t$ is the slope of the linear regression between the gas concentrations over the elapsed time ( $\mathrm{ppm} / \mathrm{min})$. A nonzero flux was reported only when the regression coefficient $\left(R^{2}\right)$ for the linear regression was larger than 0.85 [6]; otherwise a zero flux was reported [19].

\section{Geospatial Analysis}

In the current study, the geospatial analysis was carried out twice: once for the wet season emission measurements and once again for the dry season measurements. A total of 81 sample points were used to estimate the mean geospatial $\mathrm{CH}_{4}$ and $\mathrm{CO}_{2}$ emissions values for each season. The geospatial analysis was performed using Surfer 8 software. Variograms modeling the $\mathrm{CH}_{4}$ and $\mathrm{CO}_{2}$ emission measurements were generated following [14]. The variogram model structures were used with the point kriging method to develop contour maps for both the $\mathrm{CH}_{4}$ and $\mathrm{CO}_{2}$ emissions. The measured emission values were overlaid onto the contour maps to show the differences between the measured and the values estimated by the models. The net volumes of the total $\mathrm{CH}_{4}$ and $\mathrm{CO}_{2}$ emissions from the entire area were estimated by subtracting the volume of the negative contour emissions from that of the positive contour emissions. The mean geospatial $\mathrm{CH}_{4}$ and $\mathrm{CO}_{2}$ emissions values were then calculated by dividing the net emission volume by the total area.

\section{E. Statistical Analysis}

The parametric independent-samples T-test was used to investigate significant seasonal variations of $\mathrm{CH}_{4}$ and $\mathrm{CO}_{2}$ emissions. The statistical analyses were performed using SPSS 16.0.

\section{RESULTS AND DiSCUSSION}

\section{A. $\mathrm{CH}_{4}$ and $\mathrm{CO}_{2}$ Flux Measurements}

The summary and descriptive statistics of the $\mathrm{CH}_{4}$ and $\mathrm{CO}_{2}$ flux measurements during both seasons are listed in Table II.

\begin{tabular}{lcc} 
TABLE II: DESCRIPTIVE STATISTICS OF $\mathrm{CH}_{4} \mathrm{AND} \mathrm{CO}_{2}$ EMISSIONS $\left(\mathrm{G} \mathrm{M}^{-2} \mathrm{D}^{-1}\right)$ \\
\hline \hline Season & Wet & Dry \\
Properties & $n=81$ & $n=81$ \\
\hline Methane flux & 0 & 0 \\
Minimum & 120 & 89 \\
Median & 1,602 & 925 \\
Maximum & 267.3 & 181.9 \\
Mean & 329.5 & 204.3 \\
Standard deviation $(s)$ & & 10 \\
Carbon dioxide flux & 5 & 193 \\
Minimum & 244 & 1,788 \\
Median & 2,753 & 339 \\
Maximum & 477.1 & 355.7 \\
Mean & 457.6 & \\
Standard deviation $(s)$ & & \\
\hline \hline
\end{tabular}

TABLE III: GEOSPATIAL MEANS OF THE $\mathrm{CH}_{4}$ AND $\mathrm{CO}_{2}$ EMISSIONS Emission Geospatial mean $\left(\mathrm{g} \mathrm{m}^{-2} \mathrm{~d}^{-1}\right)$

\begin{tabular}{lcc} 
& Wet Season & Dry Season \\
\hline $\mathrm{CH}_{4}$ & 267.2 & 173.3 \\
$\mathrm{CO}_{2}$ & 482 & 326.2
\end{tabular}

The maximum and minimum $\mathrm{CH}_{4}$ emissions during the wet and dry seasons were in the range of results found by Abushammala et al. [12] and Morcet et al. [8]. The maximum and minimum $\mathrm{CO}_{2}$ emissions during the wet and dry seasons were approximately in the range of $\mathrm{CO}_{2}$ field measurements reported by Abushammala et al. [8]. The standard deviation $(s)$, mean, and median values in Table II indicated that some 
measurements exhibited highly skewed distributions for $\mathrm{CH}_{4}$ and $\mathrm{CO}_{2}$ emissions in both seasons. The variations in emission values might be due to surface cracking of the cover soil as a result of the underlying waste settling, different cover soil thickness and the vegetated areas, $\mathrm{CH}_{4}$ oxidation, and variations of $\mathrm{CH}_{4}$ and $\mathrm{CO}_{2}$ generated from underlying waste.

\section{B. Gas Seasonal Variability of $\mathrm{CH}_{4}$ and $\mathrm{CO}_{2}$ Emissions}

The geospatial means of the $\mathrm{CH}_{4}$ and $\mathrm{CO}_{2}$ emissions were evaluated and are presented in Table III. However, the results of the $\mathrm{CH}_{4}$ and $\mathrm{CO}_{2}$ emission modeling using the variogram model and counter maps generated by the Surfer 8 software are not presented within this paper.

The geospatial mean were almost identical with the arithmetic mean for each gas during the wet and dry seasons (see Tables II and Table III). This finding is consistent with the results obtained by Abushammala et al. [8], in which the geospatial and arithmetic means were almost identical. The arithmetic and geospatial means of $\mathrm{CH}_{4}$ and $\mathrm{CO}_{2}$ emissions during the wet season were higher than those in the dry season (Table II and Table III) which were consistent with the results of Wang-Yao et al. [7] and Fourie and Morris [5]. The mean value of $\mathrm{CH}_{4}$ emissions during the wet season was approximately 1.56 times higher than the mean of emissions during the dry season, while the $\mathrm{CO}_{2}$ emissions mean during the wet season was approximately 1.5 times higher than that during the dry season. This is consistent with the finding of Wang-Yao et al. [7]. Higher emissions during the wet season might be attributed to a higher waste moisture content during the wet season than the dry season, which facilitated nutrient transportation through waste layers and accelerated waste decomposition to produce more LFG.

Statistical analysis using an independent-samples T-test showed that no significant variations between the means of the transformed $\mathrm{CH}_{4}$ emissions data during the wet and dry seasons $(t=0.735 ; d f=155 ; p=0.464)$ and between the means of the transformed $\mathrm{CO}_{2}$ emissions data during both seasons $(t=0.862 ; d f=155 ; p=0.390)$.

The geospatial means ratio of $\mathrm{CH}_{4}$ to $\mathrm{CO}_{2}$ (calculated as the molar ratio assuming ideal gas) during the wet season was approximately $152.5 \% \mathrm{v} / \mathrm{v}$, which would be equivalent to emitting an LFG with approximately $60.4 \% \mathrm{CH}_{4}$ and $39.6 \%$ $\mathrm{CO}_{2}$ (assuming no other gases are present). The molar $\mathrm{CH}_{4}$ to $\mathrm{CO}_{2}$ ratio emitted during the dry season was approximately $146.5 \%$, corresponding to approximately $59.4 \% \mathrm{CH}_{4}$ and $40.6 \% \mathrm{CO}_{2}$. The relatively lower $\mathrm{CH}_{4}$ percentage and higher $\mathrm{CO}_{2}$ percentage in the LFG during the dry season compared with those during the wet season could be attributed to $\mathrm{CH}_{4}$ oxidation activity in the cover soil.

\section{CONCLUSION}

The study indicated relatively higher $\mathrm{CH}_{4}$ and $\mathrm{CO}_{2}$ emissions during the wet season than the dry season. This might be attributed to a higher waste moisture content during the wet season than the dry season, which facilitated nutrient transportation through waste layers and accelerated waste decomposition to produce more LFG. The geospatial means ratio of $\mathrm{CH}_{4}$ to $\mathrm{CO}_{2}$ calculated as the molar ratio assuming ideal gas shown higher $\mathrm{CH}_{4}$ percentage $(60.4 \%)$ and lower $\mathrm{CO}_{2}$ percentage $(39.6 \%$ ) during the wet season, while during the dry season the $\mathrm{CH}_{4}$ and $\mathrm{CO}_{2}$ percentages were 59.4 and $40.6 \%$, respectively. The relatively lower $\mathrm{CH}_{4}$ percentage and higher $\mathrm{CO}_{2}$ percentage in the LFG during the dry season compared with those during the wet season could be attributed to $\mathrm{CH}_{4}$ oxidation activity in the cover soil. It is concluded that special consideration must be given to landfill cover soil in order to enhance $\mathrm{CH}_{4}$ oxidation and, thereby, reduce $\mathrm{CH}_{4}$ emissions.

\section{ACKNOWLEDGMENT}

The authors gratefully acknowledge the Alam Flora Company staff for their assistance with this research and Tuwati B. Tuwati for his assistance with field sampling.

\section{REFERENCES}

[1] Ministry of Energy. (2004). Renewable Energy \& Energy Efficiency Component (Sub-Component III: CDM Action Plan). [Online] Available:

http://cdm.greentechmalaysia.my/up_dir/articles1016,article,1154653 437,Report_WasteSector_Summary\%20report.pdf

[2] G. P. Livingston and G. L. Hutchinson, "Enclosure-based measurement of trace gas exchange: applications and sources of error," Biogenic Trace Gases: Measuring Emissions from Soil and Water, 1995, pp. $14-51$

[3] I. C. Chen, U. Hegde, C. H. Chang, and S. S. Yang, "Methane and carbon dioxide emissions from closed landfill in Taiwan," Chemosphere, vol. 70, pp. 1484-1491, 2008.

[4] T. Ishigaki, M. Yamada, M. Nagamori, Y. Ono, and Y. Inoue, "Estimation of methane emission from whole waste landfill site using correlation between flux and ground temperature," Environ. Geol., vol. 48, pp. 845-853, 2005.

[5] C. Maurice and A. Lagerkvist, "LFG emission measurements in cold climatic conditions: seasonal variations and methane emissions mitigation," Cold Regions Science and Technology, vol. 36, pp. 37-46, 2003.

[6] C. Sha, W. J. Mitsch, U. Mander, J. Lu, J. Batson, L. Zhang, and W. He, "Methane emissions from freshwater riverine wetlands," Ecol. Eng., vol. 37, pp. 16-24, 2011

[7] H. Zhang, P. He, and L. Shao, "Methane emissions from MSW landfill with sandy soil covers under leachate recirculation and subsurface irrigation," Atmospheric Environment, vol. 42, pp. 5579-5588, 2008.

[8] M. Morcet, C. Aran, J. Bogner, J. Chanton, K. Spokas, and I. Hebe, "Methane mass balance: A review of field results from three French landfill case studies," in Proc. Sardinia, 9th Int. Waste Management and Landfill Symposium, CISA, Environmental Sanitary Engineering Centre, Italy, 2003.

[9] J. K. M. Einol, K. M. Sormunen, and J. A. Rintala, "Methane oxidation in a boreal climate in an experimental landfill cover composed from mechanically biologically treated waste," Science of the Total Environment, vol. 407, pp. 67-83, 2008.

[10] A. B. Fourie and J. W. F. Morris, "Measured gas emissions from four landfills in South Africa and some implications for landfill design and methane recovery in semi-arid climates," Waste Management and Research, vol. 22, pp. 440-453, 2004.

[11] K. Wang-Yao, S. Towprayoon, C. Chiemchaisri, S. H. Gheewala, and A. Nopharatana, "Seasonal variation of landfill methane emissions from seven solid waste disposal sites in central Thailand," presented at the 2nd Joint Int. Conference on Sustainable Energy and Environment (SEE), Bangkok, Thailand, 2006.

[12] M. F. M. Abushammala, N. E. A. Basri, H. Basri, A. A. H. Kadhum, and A. H. El-Shafie, "Methane and carbon dioxide emissions from Sungai Sedu open dumping during wet season in Malaysia," Ecological Engineering, vol. 49, pp. 254-263, 2012.

[13] D. J. Mulla and A. B. McBratney, "Soil spatial variability," Soil Physics Companion, USA: CRC Press, 2002, pp. 343-373.

[14] M. F. M. Abushammala, N. E. A. Basri, H. Basri, A. A.H. Kadhum, and A. H. El-Shafie, "Empirical gas emission and oxidation measurement at cover soil of dumping site: Example from Malaysia," Environmental Monitoring and Assessment, vol. 185, pp. 4919-4932, 2013. 
[15] J. C. Stern, J. Chanton, T. Abichou, D. Powelson, L. Yuan, S. Escoriza, and J. Bogner, "Use of biologically active cover to reduce landfill methane emissions and enhance methane oxidation," Waste Manage, vol. 27, pp. 1248-1258, 2007.

[16] S. Eun, D. R. Reinhart, C. D. Cooper, T. G. Townsend, and A. Faour, "Hydrogen sulphide flux measurements from construction and demolition debris (C\&D) landfills," Waste Manage., vol. 27, pp. 220-227, 2007.

[17] X. Cheng, Y. Luo, Q. Xu, G. Lin, Q. Zhang, J. Chen, and B. Li, "Seasonal variation in $\mathrm{CH}_{4}$ emission and its $13 \mathrm{C}$-isotopic signature from Spartina alterniflora and Scirpus mariqueter soils in an estuarine wetland," Plant Soil, vol. 327, pp. 85-94, 2010

[18] B. Eklund, "Practical guidance for flux chamber measurements of fugitive volatile organic emission rates," J. Air Waste Manage. Assoc., vol. 42, pp. 1583-1591, 1992.

[19] T. Abichou, D. Powelson, J. Chanton, and S. Escoriaza, "Characterization of methane oxidation at a solid waste landfill," $J$. Environ. Eng., ASCE, vol. 132, pp. 220-229, 2006.

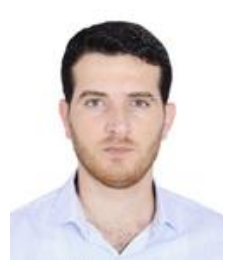

Mohammed F. M. Abushammala is an assistant professor in environmental engineering at the Department of Civil Engineering, Middle Eas College, Knowledge Oasis Muscat, Oman.

Noor Ezlin Ahmad Basri is an associate professors at the Faculty of Engineering and Built Environment, The National University of Malaysia (UKM), Bangi-Selangor, Malaysia.

Mohammad K. Younes is a $\mathrm{PhD}$ student at the Department of Civil and Structural Engineering, Faculty of Engineering and Built Environment, National University of Malaysia (UKM), Bangi-Selangor, Malaysia 